\title{
Whey Valorisation of Probiotic Fermented Milk
}

\author{
Nur Laili Ma'rufah*, Trijoko Wisnu Murti, Z Nurhanifah and M Devina
}

\author{
Laboratory of Dairy Science and Milk Industry, Department of Animal Production, Faculty of Animal Science, \\ Universitas Gadjah Mada, Jl. Fauna No. 3, Bulaksumur, Yogyakarta 55281 - Indonesia \\ *Corresponding author. Email: nurlailimarufah@ugm.ac.id
}

\begin{abstract}
Cheese making process produces whey as its by-product in which contains valuable nutrients. Whey has the potential to be utilized to reduce pollution to the environment. This study aims to compare acidity (titration), $\mathrm{pH}$ ( $\mathrm{pH}$ meter), viscosity (viscometer), and volatile compounds (GC-MS) of fermented milk using single probiotic bacteria, Bifidobacterium sp., and multi probiotic bacteria $\mathrm{ABC}$ (Lactobacillus acidophilus (A), Bifidobacterium sp., (B), and Lactobacillus casei $(\mathrm{C})$ ). Fermented milk was made from fresh cow's milk pasteurized at $76^{\circ} \mathrm{C}$ mixed with whey, inoculated with single probiotic culture as well as multi probiotic followed by incubation for 24 hours at $39^{\circ} \mathrm{C}$. Data of acidity and $\mathrm{pH}$ were analysed with split-plot design while viscosity and volatile compounds were analysed with OneWay ANOVA. Results showed that the use of single probiotic compared to multi probiotics gave highly significant differences $(\mathrm{P}<0.01)$ on quality of fermented milk which had lower $\mathrm{pH}$ value $(4.520 \mathrm{vs} 4.834)$, higher acidity $(0.551$ vs $0.386 \%)$, and thicker texture which gave significant differences $(\mathrm{P}<0.05)$ on viscosity $(925$ vs $83.75 \mathrm{cP})$. Volatile compounds detected in fermented milk both single and multi-probiotic were acetone (19 vs 4.8 ppm), acetaldehyde ( 0.18 vs $0.34 \mathrm{ppm})$, and acetic acid $(0.72$ vs $0.63 \mathrm{ppm})$. Based on the results it is concluded that whey valorisation is more effective in fermented milk using single probiotic. Furthermore, whey can be used to develop probiotic fermented milk rather than to be discarded.
\end{abstract}

Keywords: Fermented milk, Single probiotic, Multi probiotic, Whey.

\section{INTRODUCTION}

Consumer awareness for nutritional and value added obtained from food is gradually increasing. Along with better human understanding regarding importance of healthy lifestyle become opportunities for food products that gave health effects. Furthermore, food products with therapeutic properties are known as functional foods. According to Degeest [1], functional food is one of the important developments in the food industry that provide new market opportunities and forms a relationship between food, nutrition, and health. One of functional foods made from milk that is considered potential and prospective is fermented milk. Fermented milk has longer shelf life, durability and suitable for consumers who experience digestive disorders called lactose intolerance. As proposed by many researchers the use of probiotic bacteria in fermented milk aims to make the final product healthier because it will provide a therapeutic effect on the body by improving the balance of microflora in the digestive tract.

Whey is the main by-products of cheese making in the dairy industry. Despite, its potential as raw materials for development of new products is not used at all or very poorly. Whey contains highly valuable lactose, minerals (i.e calcium; sodium; potassium; magnesium; chloride; citrate; zinc), whey proteins, vitamins (i.e vit. B12; vit. B6; pantothenic acid; riboflavin; biotin; thiamine) and some fat. Other than that, whey also contains small number of organic acids and non-protein nitrogen compounds. Barukčić et al. [2] said that therapeutic value of whey is familiar since the era of ancient Greeks and was used for treatments of tuberculosis, hepatitis, diarrhea, also skin eczema. Nevertheless, the quantities of products using whey which available on the market are negligible. Whey represents a very good basis for production of beverages of excellent nutritional value on the one side, and with low energy value on the other side. It has wonderful physico-chemical characteristics that make it an exceptional substrate to be used in the development of fermented beverages [3]. Such properties are more than welcome in terms of modern consumers' demands. The objectives of this study were to see the potential use of sweet whey from hard cheese manufacturing by developing fermented milk supplemented with well-known probiotic bacteria either single or mix bacteria cultures. 


\section{MATERIALS AND METHOD}

\subsection{Materials}

Materials in the research consist of fresh milk, chemical reagents, distilled water, analytical balance, measuring cup, pipette, Kjeldahl tube, beaker glass, Lowry's solution, Babcock tube, Erlenmeyer, burette, stative, thermometer, test tube, rennet, incubator, cream separator, probiotic bacterial culture, MRS Broth, peptone water, $\mathrm{pH}$ meter (Hanna), Brookfield viscometer model LV (Brookfield Laboratories Inc., Stoughton, MA), Gas Chromatography-Mass Spectrometry (GCMS) headspace static system (Shimadzu).

\subsection{Method}

Methods of the research are the preparation of bacterial culture [4], quality analysis ( $\mathrm{pH}$, acidity), protein analysis (Kjeldahl method), fat (Babcock method), viscosity (Brookfield viscometer), analysis of whey protein content (the Lowry method), analysis of volatile compounds (GC-MS).

Fermented milk was made from fresh cow's milk pasteurized at $76^{\circ} \mathrm{C}$ mixed with whey $5 \% \mathrm{v} / \mathrm{v}$, inoculated with single probiotic culture (Bifidobacterium sp.) as well as multi probiotic ABC, Lactobacillus acidophilus (A), Bifidobacterium sp., (B), and Lactobacillus casei (C) followed by incubation for 24 hours at $39^{\circ} \mathrm{C}$. Fermented milk was divided into several sample bottles to observe $\mathrm{pH}$ and acidity at $0,2,4,6,8$, and 24 hours, while the measurement of viscosity and volatile compounds was only carried out at the final 24 hours.

Acidity and $\mathrm{pH}$ were analysed with split-plot design while viscosity and volatile compounds were analysed with One-Way ANOVA [5].

\section{RESULTS AND DISCUSSION}

\subsection{Raw Material Quality}

Raw material used in the research is fresh cow's milk and whey. Quality of cow's milk and whey are shown in Table 1 .

Results showed that cow's milk used for fermented milk met the National Standard of Indonesia (SNI) in Murti et al. [4], such as $\mathrm{pH}$ value ranged from 6.3, protein-fat content minimum $2.8 \%$ and $3 \%$. Meanwhile, analysis of protein, fat, and lactose content was carried

Table 1. Raw material quality

\begin{tabular}{|l|l|l|}
\hline Fermented milk & $\begin{array}{l}\text { Fresh cow's } \\
\text { milk }\end{array}$ & Whey \\
\hline $\mathrm{pH}$ & 6.923 & - \\
\hline Acidity & $0.053 \%$ & - \\
\hline Protein & $2.312 \%$ & $4.35 \mathrm{mg} / \mathrm{ml}$ \\
\hline
\end{tabular}

out to determine the composition of whey added in the fermented milk. Table 1 show that whey contains protein and lactose which can be source of energy for the growth of probiotic bacteria. Thermophilic bacteria such as Streptococcus or Lactobacillus will use them to produce lactic acid. The use of whey also provides peptides and amino acids as growth factors needed by probiotic bacteria [6]

\subsection{Fermented Milk Quality}

Acid production causes changes in the acidity of milk, resulting a decrease in $\mathrm{pH}$. Measurement of $\mathrm{pH}$ and acidity of single and multi-probiotic fermented milk is indicated as a parameter of bacterial growth in the

Table 2. $\mathrm{pH}$ value and acidity of single and multi-probiotic fermented milk

\begin{tabular}{|l|l|l|l|l|l|l|l|}
\hline \multirow{2}{*}{ Fermented milk } & \multicolumn{2}{|l|}{ Incubator time } \\
\cline { 2 - 8 } & 0 & 2 & 4 & 6 & 8 & 24 & Average \\
\hline pH value & & & & & & & \\
\hline Single probiotic & 5.615 & 4.940 & 4.393 & 4.233 & 4.035 & 3.905 & $4.520^{\mathrm{a}}$ \\
\hline Multi probiotic & 5.803 & 4.895 & 4.758 & 4.683 & 4.535 & 4.330 & $4.834^{\mathrm{b}}$ \\
\hline Average & $5.709^{\mathrm{a}}$ & $4.918^{\mathrm{b}}$ & $4.576^{\mathrm{c}}$ & $4.458^{\mathrm{c}}$ & $4.285^{\mathrm{cd}}$ & $4.118^{\mathrm{d}}$ & \\
\hline Acidity & & & & & & & \\
\hline Single probiotic & 0.213 & 0.393 & 0.585 & 0.635 & 0.675 & 0.803 & $0.551^{\mathrm{a}}$ \\
\hline Multi probiotic & 0.208 & 0.275 & 0.403 & 0.435 & 0.455 & 0.538 & $0.386^{\mathrm{b}}$ \\
\hline Average & $0.211^{\mathrm{a}}$ & $0.334^{\mathrm{a}}$ & $0.494^{\mathrm{b}}$ & $0.535^{\mathrm{bc}}$ & $0.565^{\mathrm{bc}}$ & $0.671^{\mathrm{c}}$ & \\
\hline
\end{tabular}

a,b,c,d: Means in the same column with different superscripts differ significantly $(\mathrm{P}<0.01)$ 
fermentation process. $\mathrm{pH}$ value and acidity of single and multi-probiotic fermented milk was presented in Table 2.

There was degradation in the $\mathrm{pH}$ value of single and multi-probiotic fermented milk. Changes in $\mathrm{pH}$ are caused by the formation of organic acids by lactic acid bacteria in milk [7]. Nagawa et al. [8] stated that the $\mathrm{pH}$ of bifidus milk at 24 hours of incubation was in the range of 4. This indicates that the use of single probiotics compared to multi probiotics influences the $\mathrm{pH}$ value of fermented milk. Calcium-phosphate or calcium-lactate complexes formed initially could be responsible for inducing further attraction with proteins and hence facilitating protein aggregation with increasing $\mathrm{pH}$ and temperature [9].

Optimum growth of Lactobacillus acidophillus occurred at $\mathrm{pH} 5.5$ to 6 at a temperature of 35 to $40^{\circ} \mathrm{C}$ [6] while Bifidobacterium sp. at $\mathrm{pH} 6$ and 7 and grows slowly at $\mathrm{pH} 4.5$ to 5 or below with optimum growth temperature ranging from 37 to $41^{\circ} \mathrm{C}$ [6]. Other than $\mathrm{pH}$ value, the results of the acidity levels for single and multi-probiotic fermented milk can be seen below. Donkor [6] stated that nutrient supplementation has a significant effect on the acidity of fermented milk products because it allows probiotic bacteria to have a suitable medium for their growth.

\subsection{Viscosity}

Factors that play an important role in assessing the quality of fermented milk related to viscosity. Viscocity of single and multi-probiotic fermented milk (cP) was presented in Table 3.

Table 3. Viscocity of single and multi-probiotic fermented milk $(\mathrm{cP})$

\begin{tabular}{|l|l|l|}
\hline Parameters & Probiotic & Average \\
\hline Viscocity & Single & $925 \pm 247.48^{\mathrm{a}}$ \\
\hline & Multi & $83.75 \pm 5.3^{\mathrm{b}}$ \\
\hline
\end{tabular}

${ }^{\mathrm{a}, \mathrm{b}}$ : Means in the same column with different superscripts differ significantly $(\mathrm{P}<0.05)$

Viscosity is one of the parameters that determine consumer acceptance of fermented milk [4]. Viscosity increases because of high acid content in fermented milk (lactic acid, acetic acid, and other organic acids) causes the $\mathrm{pH}$ to drop to the isoelectric point, resulting in protein coagulation. New oligosaccharide may have been developed due to the transgalactosydic reaction. The enzymes $\beta$-galactosidase secreted by probiotics [10] can produce variable amounts of oligosaccharide which rise viscosity of products [11] and act as viscosifiers. The inclusion of health promoting bacteria into whey induces unique flavor profiles and texture and the major difference among products, apart from the amount and type of supplementation, is the specific organism used as a probiotic [12].

\subsection{Volatile Compounds}

Analysis of volatile compounds was carried out using Gas Chromatography-Mass Spectrometry (GC-MS) as an objective sensory analysis to detect the presence of key aroma compounds that plays role in the formation of fermented milk flavor. Microorganisms produce several components that contain organic acids such as acetic acid, alcohol (especially ethanol), aldehydes and ketones (acetaldehyde, acetoin, 2-methyl butanol) [13]. Volatile compounds concentration of fermented milk (ppm) was presented in Table 4.

Table 4 was showed that volatile compounds detected were acetone, acetaldehyde, and acetic acid. According to Fu'adi (1998) cit Nurhanifah [14], components in milk that play a major role in producing acetaldehyde are lactose (especially the glucose fraction) and amino acids, while acetone is the result of lipids chemical process. Acetic acid detected was produced by the activity of

Table 4. Volatile compounds concentration of fermented milk (ppm)

\begin{tabular}{|l|l|l|l|}
\hline \multirow{2}{*}{$\begin{array}{l}\text { Fermented } \\
\text { milk }\end{array}$} & \multicolumn{3}{|c|}{ Concentration (ppm) } \\
\cline { 2 - 4 } & Acetone* $^{*}$ & Acetaldehyde & $\begin{array}{l}\text { Acetid } \\
\text { acid }^{\text {ns }}\end{array}$ \\
\hline $\begin{array}{l}\text { Single } \\
\text { probiotic }\end{array}$ & $19 \pm 0.28$ & 0.18 & $0.72 \pm 0.34$ \\
\hline $\begin{array}{l}\text { Multi } \\
\text { probiotic }\end{array}$ & $4.8 \pm 3.39$ & $0.34 \pm 0.11$ & $0.63 \pm 0.29$ \\
\hline
\end{tabular}

a,b: Means in the same column with different superscripts differ significantly $(\mathrm{P}<0.05)$

lactose metabolism by Bifidobacterium $s p$. Hoier [15] stated that Bifidobacterium sp. during the fermentation process produces acetic and lactic acid in a ratio of 3:2. Acetic acid is a volatile fatty acid that affects the $\mathrm{pH}$ value, acidity, and odor of fermented milk.

\section{CONCLUSION}

Based on the results of the study, it was concluded that whey can be used in the development of milk-based functional foods which is fermented with single and multi-probiotic bacteria. Whey supplementation in the manufacture of probiotic fermented milk provides characteristics of fermented products that consumers will like, namely taste, texture, and aroma.

\section{REFERENCES}

[1] Degeest, B. 2003. Current Development of Probiotics as Functional Foods In Europe. Int Conference Functional and Health Foods: Market, Technology and Health Benefit. Universitas Gadjah Mada, Yogyakarta. 
[2] Barukčić I., K. L. Jakopović, and R. Božanić. 2019. Whey and Buttermilk as Functional Beverages. Food Technology and Biotechnology 57 (4). (in press).

[3] Molero, M. S. and W. J. Briñez. 2018. Probiotics Consumption Increment through the Use of WheyBased Fermented Beverages. Intech Open 72362.

[4] Murti, T. W., B. T. Santoso, and A. Latif. 2019. The quality of low-fat fermented goat milk and low-fat fermented cow milk containing probiotic cultures. IOP Conf. Ser.: Earth and Environ. Sci. 387012132.

[5] Astuti, M. 2007. Pengantar Ilmu Statistik untuk Peternakan dan Kesehatan Hewan. Binasti Publisher, Bogor.

[6] Donkor, O. N. 2007. Influence of Probiotics Organism on Release of Bioactive Compounds in Yoghurt and Soy Yoghurt. Ph.D. Thesis. Victoria University. Melbourne.

[7] Vinderola, C. G., W. Prosello, D. Ghiberto, and J. A. Reinheimer. 2000. Viability of probiotic (Bifidobacterium, Lactobacillus acidophilus, and Lactobacillus casei) and nonprobiotic microflora in Argentinian fresco cheese. J. Dairy Sci. 83 (9): 1905-1911.

[8] Nagawa, M., A. Nakabayashi and S. Fujino. 1988. Preparation of The Bifidus Milk Powder. J. Dairy Sci. 71:1777-1782.

[9] Chandrapala, J., M. C. Duke, S. r. Gray, B. Zisu, M. Weeks, M. Palmer, and T. Vasiljevic. 2015. Properties of acid whey as a function of $\mathrm{pH}$ and temperature. J. Dairy Sci. 98: 4352-4363.

[10] Patel, A. K., P. Michaud, R. R. Singhania, C. R. Soccol, and A. Pandey. 2010. Polysaccharides from probiotics: New development as food additives. Food Technology and Biotechnology 48 (4) 451463.

[11] Zarate, S. and M. H. Lopez-Leiva. 1990. Oligosaccharide formation during enzymatic lactose hydrolysis: a literature review. J. Food Prot. 53 (3) 262-8.

[12] Goyal, N. and D. N. Gandhi. 2008. Whey, a carrier of probiotics against diarrhoea. [On-line]. Available from: https://www.dairyscience.info/index.php/pro biotics/110-wheyprobiotics.html?jjj=1631968766035. Accessed: 18 September, 2021.

[13] Campbell-Plat, G. 1994. Fermented Foods: A world perspective. Food Res. Int. 27:253.

[14] Nurhanifah, Z. 2011. Pengaruh Penggunaan Single Probiotik Dibanding Multi Probiotik Terhadap
Kualitas Susu Fermentasi yang Disuplementasi Whey Limbah Keju. S.Pt. Thesis. Universitas Gadjah Mada. Yogyakarta.

[15] Hoier, E. 1992. Use of probiotics starter cultures in dairy products. Food Tech. Australia. 44:418-420 